\title{
Purification and Characterization of a Detergent Compatible Alkaline Protease Produced by Bacillus ruris Isolated from Vegetable Oil Factory Effluent in Owo, Ondo State, Nigeria
}

\author{
Adebayo Olawande OSESUSI ${ }^{*}$, Victor Olusegun OYETAYO and Daniel Juwon \\ AROTUPIN
}

Department of Microbiology, Federal University of Technology Akure, P.M.B. 704. Akure. Nigeria.

Received: March 19, 2020; Revised: September 7, 2020; Accepted: Oct 2, 2020

\begin{abstract}
A thermostable alkaline protease was produced by Bacillus ruris isolated from vegetable oil factory effluent in Owo, Ondo State, Nigeria. Detergents containing enzymes have been reported to possess more effective washing capabilities. The protease was purified and characterized. Biochemical characterization and 16S rRNA sequencing showed the strain was closely related to Bacillus ruris with accession number NR_042161.1. The protease was purified with a 0.516 purification fold and $19 \%$ recovery with a Sephadex G-100 column fraction. The protease was relatively stable at alkaline $\mathrm{pH}$ retaining activity at $\mathrm{pH} 9.0(100 \%)$. The protease was also thermally stable with the highest activity observed at $55{ }^{\circ} \mathrm{C}$. Bacillus ruris protease activity was stimulated by $\mathrm{Ba}^{2+}, \mathrm{Ca}^{2+}, \mathrm{Cu}^{2+}$ and $\mathrm{Mn}^{2+}$, while enzyme activity was inhibited by $\mathrm{Zn}^{2+}$ and $\mathrm{Pb}^{2+}$. Protease activity increased with an increase in substrate concentration. The Lineweaver-burk plot revealed $\mathrm{Km}=0.14$. Protease activity was influenced by the tested surfactants and inhibitors. The protease enzyme showed relative stability to some commercial detergents. Thus, the protease enzyme appears to possess properties desired for detergent formulation and inclusion in other biotechnological applications.
\end{abstract}

Keywords: Protease, enzyme activity, detergents, alkaline, Bacillus ruris, purification.

\section{Introduction}

Enzymes have been used in fermentation processes from ancient times. Earlier reports of their use were reported by the ancient Greeks who used enzymes for baking, brewing, alcohol fermentation and cheese manufacture (Sharma et al., 2017). Literature has also shown that enzymes can perform numerous roles, for example the selective manipulation of protein and lysis of fibroin clusters with advancements in analytical techniques (Sharma et al ., 2017).

Proteases are universal enzymes in nature, catalyzing the hydrolysis of protein molecules into peptides and amino acids (Matkawala et al., 2019; Sumantha et al., 2006). Proteases have attracted interests over the years, mainly because of the important roles they play in cellular metabolism and the biotechnology industry (Fatema et al., 2019; Gupta et al., 2002). Proteases are widely used in the food, laundry detergents, leather treatment, bioremediation processes and pharmaceutical industries where they mediate several changes in products taste, texture, appearance, quality and in waste recovery (Mamo \& Assefa, 2018; Saha et al., 2011; Sandhya et al., 2005; Vadlamani and Parcha, 2011). In detergency, the combined action of surfactants and enzymes aids in the removal of difficult proteinous stains from fabrics (Olsen and Falholt, 1998). Proteases can be grouped based on their sites of action as exopeptidases and endopeptidases. Proteases that cleave the peptide bond at the center of the amino or carboxyl termini of the polypeptide chain are referred to as exopeptidases, whereas endopeptidases cleave peptide bonds distant from the termini of the substrate (cut at the internal peptide bonds) (Mamo \& Assefa, 2018; Rao et al ., 1998; Yegin and Dekker, 2013). Proteases are also grouped based on their acid-base behavior viz. acid, neutral and alkaline proteases (Sandhya et al., 2005). Alkaline proteases are optically active in a neutral to basic pH (Sharma et al., 2017). They either possess a serine center or a metallo-type, and are the most researched group of enzymes and are widely used in detergents and allied industries. The high specificity of enzymatic reactions also prevents damage to fabrics and surfaces, which is a matter of concern in chemical detergents (Singh et al., 2016).

Proteases, amylases, lipases and cellulases are used in the starch, textile, detergent and baking industries, representing the second-biggest group, while proteases are the predominant enzyme type, owing to their extensive use in the cleansing and dairy industries (Nguyen et al., 2015; Kirk et al., 2002). Proteases are also used in the modification of proteins to reduce the allergenicity of cow milk for infant formula products in dairy industries (Kirk et al., 2004).

The different products in the detergent industry contain proteases as a fundamental component or ingredient and

\footnotetext{
* Corresponding author e-mail: osesusibayo@gmail.com.
} 
are used for cleaning household laundries, false teeth, or contact focal lenses (Razzaq et al., 2019). Successful deployment of enzymes is an integral part of the design and production of economical and environmental (biodegradable) friendly detergents (Dewan, 2017). Microbial alkaline sources have attracted increased demand from industries owing to their cost-adequacy, ready susceptibility to genetic manipulation and relative ease of cultivation (Razzaq et al., 2019). Also, proteases intended for use in detergent formulation need not be in the purest state, unlike those for use in pharmaceutical, medical areas that require a higher degree of purity as a necessity.

The suitability of an enzyme for detergent formulation will depend on its ability to retain its function alongside other detergent constituents such as surfactants and oxidizers under quite harsh operating conditions (Boran, 2018). It should also possess the ability to perform over a range of $\mathrm{pH}$ and temperature (Griffin et al., 1992). Certain procedures are also put in place to prevent the denaturation of the detergent enzymes (Boran, 2018). Scientists have also tried to isolate from natural environments, microbial enzymes possessing more tolerance against alkaline $\mathrm{pH}$ and chemicals in detergents (Boran, 2018), hence the need for isolation of more detergent-compatible microbial proteases.

This study investigated the production, purification and characterization of a detergent compatible protease using bacteria isolated from vegetable oil effluent soil in Owo, Ondo State, Nigeria.

\section{Materials}

\subsection{Isolation and screening of proteolytic bacteria}

Soil samples were collected from vegetable oil factory effluent dump in Owo, Ondo State, Nigeria. Isolation was done by serial dilution on a prepared nutrient agar plate (Oxoid). Single colonies were picked and purified by continuous streaking. Preliminary screening for protease production was done by subjecting the isolates to skimmed milk agar plate (SKMA) containing $(\% \mathrm{w} / \mathrm{v})$; skimmed milk powder (1.0), peptone (0.1), $\mathrm{NaCl}(0.5)$ and agar (2.0) at $\mathrm{pH} 10$, the plates were incubated at $37^{\circ} \mathrm{C}$ for $48 \mathrm{~h}$. The occurrence of clear halo zones around distinct colonies is indicative of protease production by the bacteria (Bajaj and Jamwal, 2013). Isolate that showed higher protease production potential were selected for further production and assay (Arulmani et al., 2007). Bacterial identification was carried out using morphological, biochemical characterization by $16 \mathrm{~S}$ rDNA sequencing.

\subsection{Protease production}

Bacteria selected from SKMA screening were selected for protease production. Protease production media (PPM) consisted of: $\mathrm{CaCl}_{2}(0.01 \mathrm{~g} / \mathrm{l}), \mathrm{K}_{2} \mathrm{HPO}_{4}(0.05 \mathrm{~g} / \mathrm{l})$, peptone $(1.00 \mathrm{~g} / \mathrm{l}), \mathrm{MgSO}_{4}(0.01 \mathrm{~g} / \mathrm{l})$, glucose $(0.1 \mathrm{~g} / \mathrm{l})$, at $\mathrm{pH} 7.0$ and was incubated on a shaker incubator at $37{ }^{\circ} \mathrm{C}$ for 48 hours. The cell-free supernatant was then obtained by centrifuging at $10,000 \mathrm{rpm}$ for 10 minutes at $4{ }^{\circ} \mathrm{C}$. The supernatant obtained was used as a crude protease for further studies (Guleria et al., 2016).

\subsection{Protease assay}

Protease assay was carried out using the casein-pholine method by Cupp-Enyard (2008). Casein (1\% w/v) was dissolved in $0.1 \mathrm{M}$ phosphate buffer at $\mathrm{pH} 7.0$ and was used as the substrate, $1 \mathrm{~mL}$ of the enzyme was added to the substrate and incubated at $50{ }^{\circ} \mathrm{C}$ in a water bath for one hour. The reaction was then terminated by adding $3 \mathrm{~mL}$ of the tricarboxylic acid (TCA). The reaction cocktail was centrifuged at $5000 \mathrm{rpm}$ for 15 minutes. Then $0.5 \mathrm{~mL}$ of the supernatant was drawn into a test-tube, $2.5 \mathrm{~mL}$ of 0.5 M sodium carbonate was added, vortexed well and incubated for 20 minutes. The reaction was terminated by the addition of $0.5 \mathrm{~mL}$ of $2.0 \mathrm{~N}$ Folin-phenol reagent and the absorbance was read at $660 \mathrm{~nm}$ using a UVSpectrophotometer (752Pro15041, Spectrum Lab England). Protease produced was estimated and expressed in a microgram of tyrosine liberated by $1 \mathrm{~mL}$ of the protease in 30 minutes at $30{ }^{\circ} \mathrm{C}$ in tyrosine equivalent (Akhavan and Jabalameli, 2011; Joo et al., 2002). One unit of protease activity was defined as the amount of enzyme required to liberate $1 \mu \mathrm{g}$ of tyrosine/min under standard assay conditions based on a tyrosine calibration curve (Bhagwan et al., 2015).

\subsection{Protein assay}

Total protein content was estimated following Lowry et al. (1951) using bovine serum albumin (BSA) as reference (Mothe and Sultanpuram, 2016).

\subsection{Purification of the protease enzyme}

The crude enzyme was subjected to precipitation in a salting-out process (Dixon and Webb, 1971). The precipitated fractions were dialyzed and separated using Sephadex G100 column chromatography (Ding et al., 2012; Wakil and Osesusi, 2017). The fractions obtained were pooled together and their protease activity and protein content determined. These fractions were also used for further characterization.

\section{Characterization of the purified protease enzyme}

\subsection{Effect of $p H$}

The effect of $\mathrm{pH}$ on protease stability was assessed by incubating the protease-substrate mixture in appropriate buffers at intervals of $0.5 \mathrm{pH}$ (Citrate-phosphate for $\mathrm{pH} 4$ 7 and Tris- $\mathrm{HCl}$ for $\mathrm{pH} 8$ - 11) for one hour. Protease activity was determined using the standard assay method. Protease stability was expressed as relative activity (Niyonzima and More, 2014; Priya et al., 2014).

\subsection{Effect of temperature}

The effect of temperature on the stability of protease was assessed by incubating the protease-substrate mixtures at varying temperatures $\left(20-70{ }^{\circ} \mathrm{C}\right)$ at $5{ }^{\circ} \mathrm{C}$ intervals in a water bath for one hour. Protease activity was determined using the standard assay method. Protease stability was expressed as relative activity (Niyonzima and More, 2014; Priya et al., 2014).

\subsection{Effect of metal ions}

The protease stability in the presence of metals was determined by pre-incubating the protease-substrate mixtures with metal $\left(\mathrm{Ca}^{2+}, \mathrm{Cu}^{2+}, \mathrm{Mn}^{2+}, \mathrm{Mg}^{2+}, \mathrm{Ba}^{2+}, \mathrm{Zn}^{2+}\right.$, $\mathrm{K}^{+}, \mathrm{Na}^{+}$) for one hour. Metal salt concentrations of $5 \mathrm{mM}$ 
were used. Protease activity was determined using the standard assay method. Protease stability was expressed as relative activity (Priya et al., 2014).

\subsection{Effect of substrate concentration}

The effect of varying substrate concentrations on the protease activity was determined by incubating different substrate concentrations (casein) from 0.2 to $1.2 \mathrm{mg} / \mathrm{ml}$ with protease for one hour under standard conditions. Protease activity was determined according to standard methods as previously described. The enzyme kinetics were also determined (Priya et al., 2014). The MichaelisMenten enzyme kinetic constants $\mathrm{K}_{\mathrm{m}}$ and $\mathrm{V}_{\max }$ were extrapolated from the Lineweaver-Burk plot (Priya et al., 2014).

\subsection{Effect of inhibitors and surfactants}

Protease stability to surfactants and inhibitors; tween 20 , triton X, sodium lauryl sulfate (SLS), sodium dodecyl sulfate (SDS), 2-mercaptoethanol (BME), dithiothreitol (DTT), and ethylenediaminetetraacetic acid (EDTA), were determined by pre-incubating the enzyme substrate mixtures with the surfactants and inhibitors at various concentrations for one hour at a concentration of $1 \mathrm{mM}$ (Gohel and Singh, 2018). Protease activity was carried out according to standard methods as described earlier (Matkawala et al., 2019).

\subsection{Effect of detergents}

The effect of commercial detergents (Ariel, Klin, Sunlight, Good mama, Canoe and Omo) on protease stability was evaluated by incubating detergents with the protease for one hour at $35{ }^{\circ} \mathrm{C}$. The detergent solutions $(0.1 \% \mathrm{w} / \mathrm{v})$ were prepared with double-distilled water, the detergent solutions were boiled at $100{ }^{\circ} \mathrm{C}$ to inactivate any enzymes already present, then cooled to room temperature. The solutions were then incubated with purified protease at $50{ }^{\circ} \mathrm{C}$ for one hour (Lam et al., 2018; Matkawala et al., 2019). Protease activity was determined using the standard assay method.

\section{Results and Discussions}

\subsection{Isolation of proteolytic bacteria}

The bacterial isolates that showed appreciable zone of hydrolysis on skimmed milk agar plates were subjected to protease production, and the bacteria with the highest protease production was selected for further study. Quantitative screening for protease production showed that OWO1 had the best protease activity $(2.039 \mathrm{U} / \mathrm{mL})$ while AKK1 had the lowest protease activity $(0.072 \mathrm{U} / \mathrm{mL})$ as shown in Figure 1. OWO1 was used for further study.

Vegetable oil factory effluents contain an immensely high volume of degradable organic matter. It is rich in nutrients and possesses fertilizing properties even in its raw state (Kamyab et al., 2016). The nutrient-rich nature of the effluents may thus provide a good source of nutrients for proteolytic organisms to flourish.
Microscopic identification showed the isolate as sporeforming, Gram-positive rods, having flat elevation. Further identification showed the bacteria was catalase-positive and utilized citrate, it also utilized a range of hexose sugars, and disaccharide sugars (sucrose, maltose). 16S rDNA showed the isolate to have a $95.75 \%$ homology with Bacillus ruris NR_042161.1 upon submission of the sequence to the gene data bank of National Center for Biotechnology Information (NCBI). Naidu (2011) reported Bacillus species as being excellent protease producers. Sharma et al. (2017b) highlighted microbial enzyme activity as a function of several factors including nutritional and cultural variables viz. $\mathrm{pH}$, temperature, carbon and nitrogen sources and duration of incubation of the microorganisms.

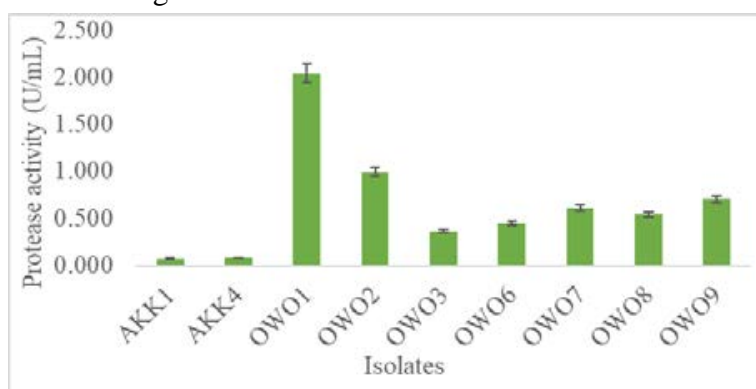

Figure 1. Screening for protease activity

The purification profile (Table I) of Bacillus ruris protease showed that the total protease activity and total protein content were reduced significantly across the purification steps with the crude fraction having the highest values. The protease purification was found to decrease from 1 to 0.516 purification fold using Sephadex G-100 column chromatography. This is similar to reports by Josephine et al. (2012) and Jayashree et al. (2014) who reported a rise in the purification fold of Bacillus spp protease (Guleria et al., 2016). This disagrees with reports by Naidu (2011) and Bajaj and Jamwal (2013) who reported increased protein content when purification was carried out to obtain the pure protease enzyme.

Bacillus ruris protease was relatively stable across varying $\mathrm{pH}$, maintaining relative stability at alkaline conditions up to $\mathrm{pH}$ 9.0, after which further rise in $\mathrm{pH}$ resulted in reduced protease activity (Figure 2). It was a good candidate for alkaline protease production, which is similar to findings by (Chu, 2007). These findings align with findings by Naidu (2011) who reported high Bacillus subtilis protease activity at $\mathrm{pH}$ 9.0. Niyonzima and More (2014) also reported that Bacillus spp. alkaline protease maintained stability within $\mathrm{pH} 8.0$ - 12.0. Jayashree et al. (2014) reported a Methylobacterium sp. protease which retained over $50 \%$ activity at $\mathrm{pH} 7.0-11.0$ but decreased to $30 \%$ beyond $\mathrm{pH} 12.0$. Takami et al. (1990) attributed the increase in protease activity around the alkaline range to the binding that occurs in the enzyme-substrate complex, because $\mathrm{pH}$ greatly influences enzyme-substrate binding (Niyonzima and More, 2014). 
Table I. Purification profile of Bacillus ruris protease

\begin{tabular}{|c|c|c|c|c|c|}
\hline Purification steps & $\begin{array}{l}\text { Total protease activity } \\
\qquad(\mathrm{U} / \mathrm{mL})\end{array}$ & $\begin{array}{l}\text { Total protein } \\
(\mathrm{U} / \mathrm{mL})\end{array}$ & $\begin{array}{c}\text { Specific activity } \\
\text { (U/mg) }\end{array}$ & Purification fold & Recovery yield \% \\
\hline Crude extract & 1432.27 & 26.88 & 53.284 & 1 & 100 \\
\hline 80\% Ammonium sulphate precipitation & 935.21 & 19.25 & 48.582 & 0.912 & 65 \\
\hline Dialysis & 657.32 & 14.13 & 46.519 & 0.873 & 46 \\
\hline Gel chromatography & 278.32 & 10.12 & 27.502 & 0.516 & 19 \\
\hline
\end{tabular}

The results showed that the protease enzyme maintained relative stability after one hour when preincubated at varying temperatures between $20-70{ }^{\circ} \mathrm{C}$ as shown in figure 3, although activity decreased with increasing temperatures. Bacillus ruris protease had its highest activity at $50{ }^{\circ} \mathrm{C}(100 \%)$, while further temperature rise resulted in reduced protease activity decreasing to $77.042 \%$ at $70{ }^{\circ} \mathrm{C}$. This result agrees with reports by (Adinarayana et al., 2003; Giri et al., 2011; Jayashree et al ., 2014; Niyonzima and More, 2014; Ramkumar et al., 2018) who reported protease stability at $50{ }^{\circ} \mathrm{C}$. This contrasts with Naidu (2011) who reported a reduction in protease activity beyond $35{ }^{\circ} \mathrm{C}$. This inherent activity of the protease at alkaline and wide temperature regimes implies its potential for use across a range of washing temperatures (Niyonzima and More, 2014).

These findings show that Bacillus ruris protease activity was stimulated by $\mathrm{Ba}^{2+}, \mathrm{Zn}^{2+}, \mathrm{Cu}^{2+}, \mathrm{Ca}^{2+}, \mathrm{Mg}^{2+}$, and $\mathrm{Mn}^{2+}$ with $\mathrm{K}^{+}$(Figure 4) supporting the least protease activity, this highlights the protease stability in the presence of metals. This result is similar to reports by (Niyonzima and More, 2015) who reported that $\mathrm{Ca}^{2+}$ and $\mathrm{Mg}^{2+}$ stimulated protease production. Anandan et al. (2007); Niyonzima and More (2015); Sharma et al. (2005); Dubey et al. (2010) and Kalpana devi et al. (2008) positioned the importance of cations in maintaining the enzyme active sites, thus, improving protease thermostability. Also, Lobedanz et al. (2016) suggested that the actions of metal ions are dependent on their ability to bind specific sites in the enzyme molecule, ensuring the stability of the active enzyme conformation.

The findings show that increased substrate concentration also resulted in increased protease activity with the highest protease activity obtained at $1.5 \mathrm{mg} / \mathrm{ml}$, while further increase in substrate concentration resulted in reduced protease activity (Figure 5). This corresponds to reports by Devanadera et al . (2016); Ramkumar et al . (2018); El-Safey and Abdul-Raouf (2004); Sumantha et al. (2006) who reported appreciable affinity for an increase in substrate concentration by protease enzyme after which further increase resulted in reduced protease production. The apparent $K_{m}$ value of protease hydrolysis indicated the higher affinity and efficient catalytic role of Bacillus species protease towards their substrates to concentrate the active sites of an enzyme Ramkumar et al. (2018), as shown in Figure 6. It is also a measure of the enzymesubstrate (ES) complex. Singh et al. (2014) and Singh and Bajaj (2017) highlighted that proteases being designed for biotechnological applications should be robust and possess the structural and kinetic adaptations essential for extremes of industrial microenvironments, such as extreme temperature, $\mathrm{pH}$ and presence of inhibitors.

Findings from this study showed that surfactants such as tween 20, triton $\mathrm{X}$, (SLS), (SDS), enhanced the protease activity of Bacillus ruris, while inhibitors such as 2- mercaptoethanol (BME), dithiothreitol (DTT), and ethylenediaminetetraacetic acid (EDTA) had varying inhibitory effects on Bacillus ruris protease as shown in Figure 7. This result is similar to reports obtained by Jayashree et al. (2014) who reported improvement of protease activity by tween 20 and triton $\mathrm{X}$ and minimal effects of the oxidizing agents on protease enzyme. Further studies on enzyme inhibition could offer more insights regarding the nature of the proteases, its cofactor requirements and its active center (Jayashree et al., 2014). The role of DTT in decreasing protease activity could be due to the excision of the intramolecular disulfide bonds essential for maintaining protease activity and stability (Jayashree et al., 2014; Satyanarayana et al., 2013 and Rai et al., 2010).

The protease maintained relative stability in the presence of some commercial detergents (Figure 8), which is similar to reports by Adinarayana et al. (2003) and Ramkumar et al. (2018) who reported enzyme addition in detergents. Bajaj and Jamwal (2013) also reported a protease from Bacillus pumilus which showed significant stability and compatibility with surfactants and commercial laundry detergents at ambient temperature.

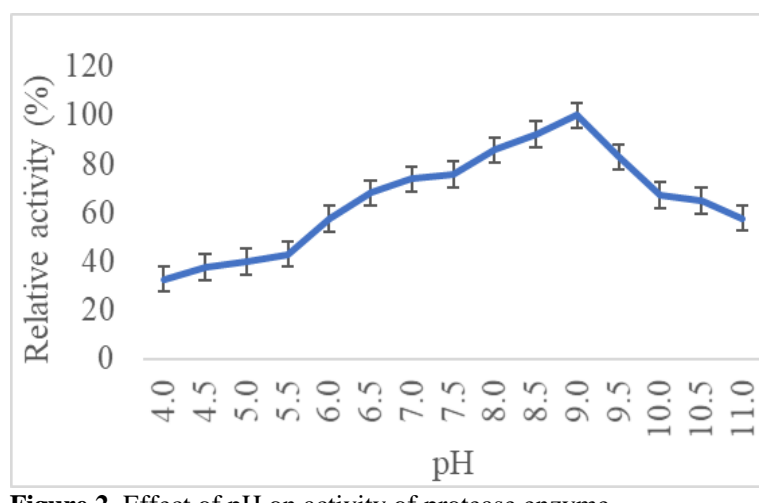

Figure 2. Effect of pH on activity of protease enzyme

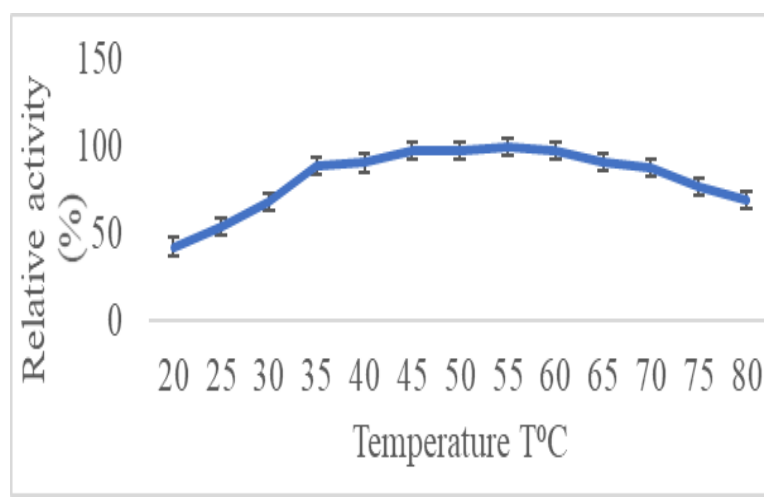

Figure 3. Effect of temperature on the activity of protease 


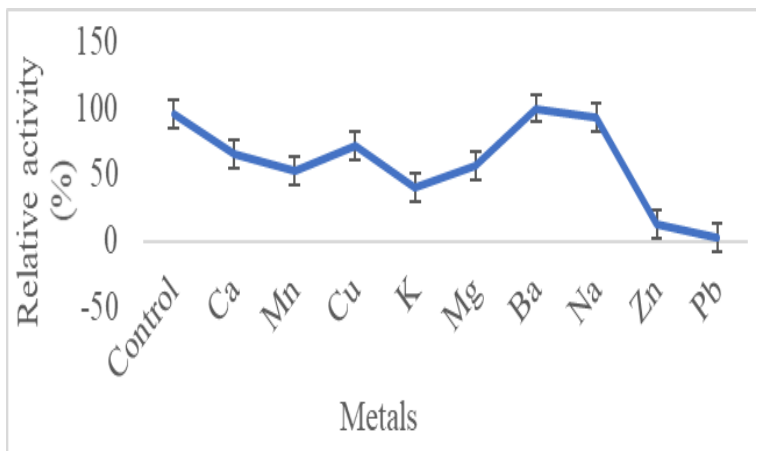

Figure 4. Effect of metal ions on protease activity
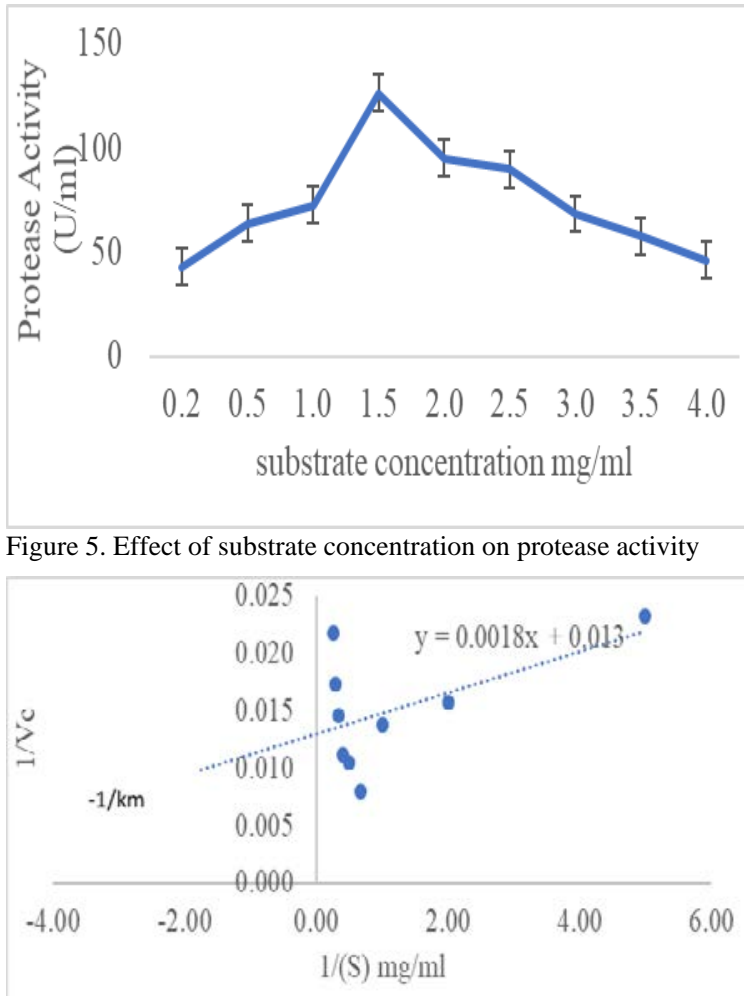

Figure 6. Lineweaver-burk plot for the hydrolysis of casein by the purified protease of Bacillus ruris

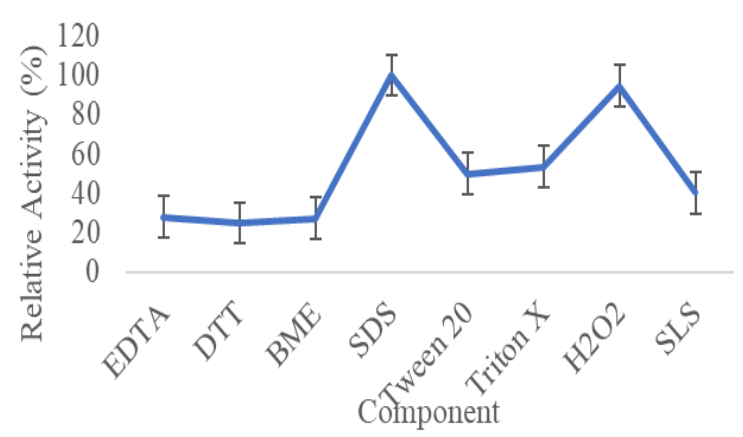

Figure 7. Effects of surfactants, inhibitors and oxidizing agents on protease activity

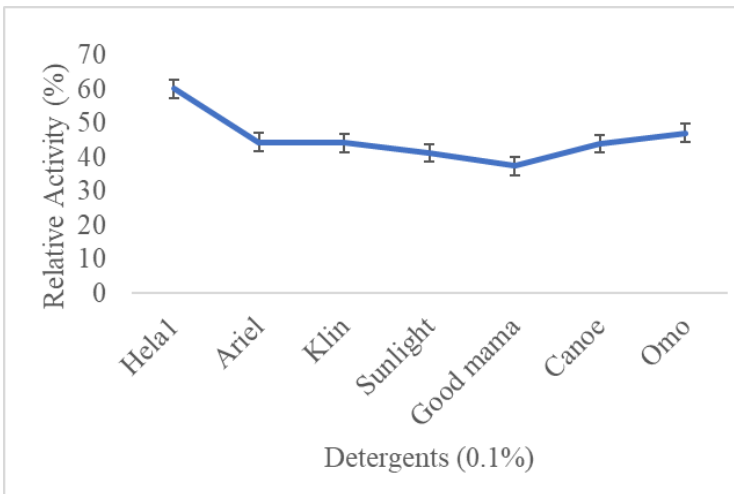

Figure 8. Protease activity in the presence of commercial detergents

\section{Conclusion}

In this study, an alkaline and thermostable protease was produced using Bacillus ruris isolated from vegetable oil effluents in submerged fermentation. The protease maintained relative stability to inhibitors and commercial detergents. Protease remains one of the most important groups of industrial enzymes with numerous biotechnological applications. This suggests its potential for inclusion in a detergent formulation as well as other biotechnological uses. Further study on the protein interactions is necessary to tailor the protease appropriately for use.

\section{Acknowledgements}

The Authors wish to acknowledge and thank Dr. Femi Bamidele of the Department of Biochemistry, Federal University of Technology, Akure.

\section{References}

Adinarayana K, Ellaiah P. and Prasad DS. 2003. Purification and partial characterization of thermostable serine alkaline protease from a newly isolated Bacillus subtilis PE-11. J. Appl. Pharm. Sci. 4(4): 1-9. doi: 10.1208/pt040456.

Akhavan Sepahy A and Jabalameli L. 2011. Effect of culture conditions on the production of an extracellular protease by bacillus sp. isolated from soil sample of lavizan jungle park. Enzyme Res. 1-7. doi: 10.4061/2011/219628.

Anandan D, Marmer WN and Dudley RL. 2007. Isolation, characterization and optimization of culture parameters for production of an alkaline protease isolated from Aspergillus tamarii. J. Microbiol Biotechnol. 34(5): 339-347. doi: 10.1007/s10295-006-0201-5.

Arulmani M, Aparanjini K, Vasanthi K, Arumugam P. 2007. Purification and partial characterization of serine protease from thermostable alkalophilic Bacillus laterosporus-AK1. World $J$. Microbiol. Biotechnol. 23(4): 475-481. doi: 10.1007/s11274-0069249-7.

Bhagwan N and Rekadwad LVG. 2015. Isolation, Identification and Oil Resistance of Protease Producing Bacillus Subtilis from Automobile Repair Centre Soil, Nanded (India). EC Bacteriol. Res. 1(1): 17-23. 
Boran R. 2018. Detergent Compatible Extracellular Lipase from Streptomyces cellulosae AU-10: A Green Alternative for the Detergent Industry. J. Surfactants Deterg. 21(4): 565-573. doi: 10.1002/jsde.12049.

Chu WH. 2007. Optimization of extracellular alkaline protease production from species of Bacillus. J. Microbiol. Biotech. 34(3): 241-245. doi: 10.1007/s10295-006-0192-2.

Devanadera M, Mark KP. 2016. Optimization, Production, Partial Purification and Characterization of Neutral and Alkaline Proteases Produced By Bacillus Subtilis. J. Microbiol. Biotech. 6(2): 832-838. doi: 10.15414/jmbfs.2016.6.2.832-838.

Dewan SS. 2017. Global Markets for Enzymes in Industrial Applications. BCC Research: Wellesly, MA, USA,.

Ding Z, Peng L, Chen Y, Zhang L, Gu Z, Shi G, and Zhang K. 2012. Production and characterization of thermostable laccase from the mushroom, Ganoderma lucidum, using submerged fermentation. Afr. J. Microbiol. Res. 6(6): 1147-1157.

Dixon M, and Webb EC. 1971. Enzymes, in Enzymes. 2nd Edition. London: Academic press. 222-234.

Dubey R, Adhikary S, Kumar J and Sinha N. 2010. Isolation, production, purification, assay and characterization of alkaline protease enzyme from Aspergillus niger and its compatibility with commercial detergent. DMMB. 1(1): 75-94.

Matkawala F, Nighojkar NA and Kumar AN. 2019. Enhanced production of alkaline protease by Neocosmospora sp. N1 using custard apple seed powder as inducer and its application for stain removal and dehairing. Biocatal. Agric. Biotechnol. 21(1): 243247.

Garg G, Singh A, Kaur A, Singh R, Kaur J and Mahajan R. 2016. Microbial pectinases: an ecofriendly tool of nature for industries. 3 Biotech, 6(1): 1-13. doi: 10.1007/s13205-016-0371-4.

Giri, SS, Giri SS, Sukumaran V, Sen SS, Oviya M, Banu BN and Jena PK. 2011. Purification and partial characterization of a detergent and oxidizing agent stable alkaline protease from a newly isolated Bacillus subtilis VSG-4 of tropical soil. $J$. Microbiol. 49(3): 455-461. doi: 10.1007/s12275-011-0427-4.

Gohel SD and Singh SP. 2018. Thermodynamics of a $\mathrm{Ca}^{2+}$ dependent, highly thermostable and detergent compatible purified alkaline serine protease from Nocardiopsis xinjiangensis strain OM-6. Int. J. Biol. Macromol. 211: 4-7.

Guleria S, Walia A, Chauhan A, Shirkot CK. 2016. Purification and characterization of detergent stable alkaline protease from Bacillus amyloliquefaciens SP1 isolated from apple rhizosphere', J. Basic Microbio. 56(2): 138-152. doi: 10.1002/jobm.201500341.

Gupta R, Beg Q and Lorenz P. 2002. Bacterial alkaline proteases: Molecular approaches and industrial applications. Appl. Microbiol. Biotechnol. 59(1): 15-32. doi: 10.1007/s00253-0020975-y.

Joo HS, Kumar CG, Park GC, Kim KT and Chang,CS. 2002. Optimization of the production of an extracellular alkaline protease from Bacillus horikoshii. Process Biochem. 38(2): 155159.
Griffin HL, Greene RV and Cotta MA. 1992. Isolation and characterization of an alkaline protease from the marine shipworm bacterium. Curr Microbiol. 24(8): 111-117.

Priya JDA, Divakar K, Prabha MS, Selvam GP and Gautam P. 2014. Isolation, Purification and Characterisation of an Organic Solvent-Tolerant $\mathrm{Ca}^{2+}$-Dependent Protease from Bacillus megaterium AU02. Appl Biochem Biotechnol. 172: 910-932.

Jayashree S, Annapurna B, Jayakumar R, Sa T and Seshadri S. 2014. Screening and characterization of alkaline protease produced by a pink pigmented facultative methylotrophic (PPFM) strain, MSF 46. J. Genet. Eng. Biotechnol. 12(2): 111-120. doi: 10.1016/j.jgeb.2014.11.002.

Kalpana devi M, Banu AR, Gnanaprabhal GR, Pradeep BV and Palaniswamy M. 2008. Purification, characterization of alkaline protease enzyme from native isolate Aspergillus niger and its compatibility with commercial detergents. Indian J Sci Tech. 1(7): $1-6$.

Kamyab H, Din MFM, Hosseini SE, Ghoshal SK, Ashokkumar V and Keyvanfar A. 2016. Optimum lipid production using agroindustrial wastewater treated microalgae as biofuel substrate. Clean Technol. Environ. Policy, 18(8): 2513-2523.

Kirk O, Borchert TV and Fuglsang CC. 2002. Industrial Enzyme Applications. Curr. Opin. Biotechnol. 4(1): 2-8

Kirk O, Ture D, Torben V, Fuglsang, CC, Olsen T and Tage LKN. 2004. Enzyme Applications, Industrial. In Kirk-Othmer Encyclopedia of Chemical Technology. 10th edn. Hoboken, NJ: John Wiley \& Son.

Kumar BB and Jamwal G. 2013. Thermostable alkaline protease production from Bacillus pumilus D-6 by using agro-residues as substrates. Adv. Enzyme Res. 01(02): 30-36. doi: 10.4236/aer.2013.12003.

Lam MQ, Nik Mut NN, Thevarajoo S, Chen SJ, Selvaratnam C, Hussin H, Jamaluddin H and Chong CS. 2018. Characterization of detergent compatible protease from halophilic Virgibacillus sp. CD6. 3 Biotech. 8(2): 1-9. doi: 10.1007/s13205-018-1133-2.

Lobedanz M, Sune TD, Torben V, Borchert TT, Hansen HL and Weijian LM. 2016. Enzymes in Industrial Biotechnology. Curr. Opin. Biotechnol.

Lowry OH, Rosebrough NJ, Farr AL and Randall RJ. 1951 Protein measurement with Folin phenol reagent.', J. Biol.. Chem. 193(1): 265--275.

Rao MB, Tanksale AM, Ghatge MS and Verna VD. 1998. Molecular and biotechnological aspects of microbial proteases. Microbiol. Mol. Biol. Rev. 62(3): 597-635.

Mamo J and Assefa F. 2018. The Role of Microbial Aspartic Protease Enzyme in Food and Beverage Industries. J. Food Qual. (20)1: 8-9. doi: 10.1155/2018/7957269.

Matkawala F, Nighojkar S, Kumar A, Nighojkar A. 2019. A novel thiol-dependent serine protease from Neocosmospora sp. N1. Heliyon. 5(8): p. e02246. doi: 10.1016/j.heliyon.2019.e02246.

Mothe T and Sultanpuram VR. 2016. Production, purification and characterization of a thermotolerant alkaline serine protease from a novel species Bacillus caseinilyticus. 3 Biotech, 6(1): 1-10. doi: 10.1007/s13205-016-0377-y. 
Nguyen QD, Erika BG, Styevkó, JM, Rezessy-Szabó A, and Hoschke Á. 2015. Fungal biomolecules for the food industry Fungal Biomolecules. 11-38.

Niyonzima, FN and More S. 2014. Detergent-compatible proteases: Microbial production, properties, and stain removal analysis. Prep. Biochem. Biotechnol. 45(3): 233-258. doi: 10.1080/10826068.2014.907183.

Niyonzima, FN and More SS. 2014. Purification and characterization of detergent-compatible protease from Aspergillus terreus gr. 3 Biotech, 5(1): 61-70. doi: 10.1007/s13205-014-0200-6.

Olsen HS and Falholt P. 1998. The role of enzymes in modern detergency. J. Surfactants Deterg. 1(4): 555-567. doi: 10.1007/s11743-998-0058-7.

Orhan E, Omay D and Güvenilir Y. 2005. Partial purification and characterization of protease enzyme from Bacillus subtilis and Bacillus cereus. Part A Enzyme Engineering and Biotechnology. Appl. Biochem. Biotechnol. 121(1-3): 183-194. doi: 10.1007/9781-59259-991-2_16.

Priya JDA, Divakar KK, Prabha MS, Selvam GP and Gautam P. 2014. Isolation, purification and characterisation of an organic solvent-tolerant $\mathrm{Ca}^{2+}$-dependent protease from Bacillus megaterium AU02. Appl. Biochem. Biotechnol. 172(2): 910-932. doi: 10.1007/s12010-013-0589-0.

Rai, SK, Roy JK and Mukherjee AK. 2010. Characterization of a detergent-stable alkaline protease from a novel thermophilic strain Paenibacillus tezpurensis sp. nov. AS-S24-II. Appl. Microbiol. Biotechnol. 2(85): 1437-1450. doi: 10.1007/s00253-009-2145-y.

Ramkumar A, Sivakumar N, Gujarathi A and Victor R. 2018. Production of thermotolerant, detergent stable alkaline protease using the gut waste of Sardinella longiceps as a substrate: Optimization and characterization. Sci. Rep., 8(1): 1-15. doi: 10.1038/s41598-018-30155-9.

Razzaq A, Razzaq A,Shamsi S, Ali A, Ali Q, Sajjad M, Malik A and Ashraf M. 2019. Microbial proteases applications. Front. Bioeng. Biotechnol., 7(6): 1-20. doi: 10.3389/fbioe.2019.00110.

Yegin S and Dekker P. 2013. Progress in the field of aspartic proteinases in cheese manufacturing: structures, functions, catalytic mechanism, inhibition, and engineering. Dairy Sci. Technol. 93(6): 565-594.

Saha ML, Begum KJMH, Khan MR and Gomes DJ. 2011. Bacterial Protease Enzyme: Safe and Good Alternative for Industrial and Commercial Use. Plant Tissue Cult. Biotechnol. 21: 53-61.

Sandhya C, Nampoothiri KM and Pandey A. 2005. Microbial protease in: Microbial Enzyme and Biotransformation. 1st Edition.
Satyanarayana T, Kawarabayasi Y and Littlechild J. 2013. Thermophilic microbes in environmental and industrial biotechnology: Biotechnology of thermophiles, Springer Netherlands. doi: 10.1007/978-94-007-5899-5.

Shanti NK. 2011. Characterization and purification of protease enzyme. J. Appl. Pharm. Sci. 1(3): 107-112.

Sharma J, Singh A, Kumar R and Mittal A. 2012. Partial Purification Of An Alkaline Protease From A New Strain Of Aspergillus Oryzae AWT 20 And Its Enhanced Stabilization In Entrapped Ca-Alginate Beads. The Intenet J. Microbiol. 2(2): 1-9. doi: 10.5580/b6f.

Sharma KM, Mageswari A, Karthikeyan S, Anbalagan M, Sivakumar A and Gothandam KM. 2017. Microbial alkaline proteases: Optimization of production parameters and their properties. J. Gen. Eng. Biotechnol. 15(1): 115-126. doi: 10.1016/j.jgeb.2017.02.001.

Singh S, Gupta P, Sharma V, Koul S, Kour K, Bajaj B and Kumar J. 2014. Multifarious potential applications of keratinase of Bacillus subtilis K-5. Biocatal. Biotransformation, 32(5-6): 333342. doi: 10.3109/10242422.2014.978306.

Singh S and Bajaj BK. 2017. Potential application spectrum of microbial proteases for clean and green industrial production Energy, Ecology and Environment, 2(6): 370-386. doi: 10.1007/s40974-017-0076-5.

Josephine SF, Ramya SV, Neelam D, Ganapa B, Suresh G and Siddalingeshwara K. 2012. Isolation, production and characterization of protease from Bacillus sp isolated from soil sample. J. Microbiol. Biotech. Res. 2(1): 163-168.

Sumantha A, Deepa P, Sandhya C, Szakacs G, Soccol CR and Pandey A. 2006. Rice bran as a substrate for proteolytic enzyme production. Braz. Arch. Biol. Technol. 49(5): 843-851. doi: 10.1590/S1516-89132006000600019.

Sumantha A, Larroche C and Pandey A. 2006. Microbiology and industrial biotechnology of food-grade proteases:A perspective', Food Technol. Biotechnol. 44(2): 211-220.

Takami H, Akiba T. and Horikoshai K. 1990. Characterization of an alkaline protease from Bacillus sp. no. AH-101. Appl. Microbio. Biotechnol. 33(5): 519-523.

Lowry OH, Rosebrough NJ, Farr AL and Randall RJ. 1951. Protein Determination. Modified Lowry Method 193: 7-9.

Vadlamani S and Parcha SR. 2011. Studies on industrially important alkaline protease production from locally isolated superior microbial strain from soil microorganisms. Int. J. Biotechnol. Appl. 3: 102-105.

Wakil SM and Osesusi AO 2017. Production, Characterization And Purification Of Lipase By Bacteria Isolated From Palm Oil Mill Effluent And Its Dumpsites Soil. NJM, 31(1): 3691-3703. 